\title{
Corporate Taxation in the Context of Tax Competitiveness of EU States
}

DOI 10.18267/pr.2021.krn.4816.3

\author{
Martina Helcmanovská ${ }^{1}$ - Alena Andrejovská2 \\ ORCID iD: 0000-0002-9001-78391, 0000-0001-5954-3008² \\ martina.helcmanovska@tuke.sk, alena.andrejovska@tuke.sk \\ 1,2 Technical University of Košice, Faculty of Economics, Department of Finance \\ Košice, Slovakia
}

\begin{abstract}
The tax burden significantly affects the development of individual economies in EU member states. Despite efforts to harmonize and coordinate tax coordination, the tax burden can vary considerably between states. This difference may have an impact on the investment strategy of an investor who is interested in corporate taxation in a given state, among other factors. The aim of this paper was to empirically verify the impact of changes in corporate taxation on tax competitiveness in EU states for the period 2004-2019. The analysis was performed using the method of constant tax shares and the rate relation method. The research was complemented by the hypothesis that the new EU member states are more competitive than the old EU member states, and this was confirmed. In conclusion, we state that the decline in tax rates is related to the growth of tax competition between EU member states. Tax competitiveness will exist until full harmonization of the tax system.
\end{abstract}

Keywords: tax competitiveness, EU member states, corporate taxation, method of constant tax shares, method of rate relation

JEL Classification codes: F62, H26, 052

\section{INTRODUCTION}

The competitiveness of EU states is a central theme of the whole contribution, which states can use to attract investors in the context of changes in the tax burden. Tax competitiveness is a form of competition that has developed in the global economy. The process of gradual globalization is responsible for the emergence of functional relations between states and connections between economies, which also increases the responsibility of states for competitiveness. Legal and macroeconomic environment, the workforce in connection with tax burdens can create an environment in which the state can be more attractive to the investor it wants to attract. Under tax competition, we can imagine a process in which a state seeks to attract investment to the state by influencing the amount of the tax burden in the form of changes in tax rates. As a result of corporate taxation and income from financial capital, the importance of tax management in companies is increasing, while those that do so show lower indebtedness. It is the difference in corporate taxation that is one of the factors that interests investors in their investment strategy and may favor one state over another.

\section{LITERATURE REVIEW}

The problem of corporate tax, which is a corporate income tax, is extremely complicated. Corporate taxation in the state can result in both corporate investment and economic growth 
in the economy as a whole. Despite competing with each other, national economies are becoming interdependent through globalization, internationalization and integration. Governments seek to maintain tax competition and transnational integrations seek to harmonize taxes.

The European Union has been addressing the issue of tax competition since its inception. According to Hameakers (1993), tax competition results in a spontaneous harmonizing effect. He considers tax rates, especially their reduction, to be a tool for states' competitiveness. EU member states are seeking to attract investors by reducing corporate tax rates, as evidenced by the fact that they have fallen sharply over the last decades. The free movement of capital between the borders of EU member states also contributes to increasing competition between states.

Tiebout (1956) was one of the first to carry out a tax competitiveness study on competition between local governments. The results showed that the tax base goes to a state where the ratio of the amount of public services and the tax burden reaches the optimal value. Bradford and Oates (1971) and Oates (1972) found that governments provide local public goods in an effort to attract mobile factors.

Authors such as Wilson (1999), Teera and Hudson (2004), Devereux et al. (2008), Devereux and Loretz (2012) and Haufler and Stähler (2013) dealt with tax competition. They are inclined to the fact that the level of the tax burden in the form of a statutory tax rate is, among other factors, one of the fundamental instruments of tax competitiveness. The authors agree that higher tax rates in the state may not immediately mean an unsuitable investment environment. The investor is also interested in the overall economic health in the state, such as quality and well-developed infrastructure, a long-term sustainable macroeconomic environment and good provision of public services. They also stress that low tax rates may not immediately mean the possibility of a suitable investment if they are not linked to the other factors already mentioned. However, according to Bunn and Asen (2019), a high tax burden in a state could lead to tax avoidance and could lead to investments being directed to another state.

If we summarize the authors' statements on the effects of tax competition, we find that they are clearly different. Authors such as Wigger and Wartha (2003), Smith (2008) and Kubátová (2014) consider it positive for economic growth. They argue that it has a positive effect on the growth of tax collection and the efficiency of public finances, while allowing the public sector to grow and limiting the growth of the private sector. Wilson (1999) and Stiglitz and Rosengard (2015) consider the impossibility of securing tax resource allocations, which weakens revenues, as negative effects of tax competition.

\section{METHODOLOGY}

The aim of the paper was to analyze the impact of changes in corporate taxation on tax competitiveness in EU states. The first part deals with the method of constant tax shares, which is used to assess the tax competitiveness of EU states. The second part evaluates the impact of changes in tax rates using the method of rate relation.

The stated goal of the analysis is followed by a hypothesis, which assumes that:

H1: The new EU member states are more competitive than the old EU member states.

The choice of methods is based on the theoretical knowledge of the authors: Tyzsinski (1951), Richardson (1971), Ahmadi-Esfahani and Anderson (2006), Jiménez and Martín (2010) and Dyadkova and Momchilov (2014), who used the constant market share method to evaluate export economic growth. Authors such as Kubátová $(2009,2014)$ and Mihóková et al. (2018) in their research, among other things, applied the modified market share method to the 
constant tax share method and dealt with the impact of tax rates on the change in tax competitiveness as well as on the change in tax revenues in EU states.

The EUROSTAT statistical database and European Commission documents provided the basic data needed to calculate the methods of constant tax shares and rates. Due to the achievement of the extreme value, Hungary was excluded from the calculations and in the paper we work with data from 27 EU member states. The period from 2004 to 2019 was monitored. The year 2004 is considered to be the initial year $\left(t_{0}\right)$ in which a number of states that we consider to be new EU member states joined the EU, while the old member states are those that joined the EU. 2004. Due to the availability of data, 2019 represents the current year $\left(t_{1}\right)$.

\section{Method of constant market / tax shares}

The method of constant market shares is used to calculate the export performance of economies. The method is applied to the analysis of exports in the state and compares it with competitors. As Dyadkova and Momchilov (2014) mention, the method analyzes whether there is a dependence between the competitiveness performance of one state and the growth of competitiveness in other states. The theory is based on the assumption of the "relative competitiveness" of each state's export share (Ahmadi-Esfahani \& Anderson, 2006).

The variable designations are as follows:

$e_{i}^{t}$ - export of the state $(i)$ at time $t$,

$E^{t}$ - total exports of states at time $t$,

$s_{i}^{t}$ - export share of the state $(i)$ at time $t$,

while applicable: $s_{i}^{t}=\frac{e_{i}^{t}}{E^{t}}$, and therefore: $e_{i}^{t}=s_{i}^{t} \times E^{t}$.

They are still marked:

$c_{i}^{t}$ - competitiveness of the state $(i)$ at time $t$,

$C^{t}$ - competitiveness of all states at time $t$,

$\frac{c_{i}^{t}}{c^{t}}-$ the share of the state's competitiveness $(i)$.

We can denote it as a function of time $e_{i}^{t}=s_{i}^{t} \times E^{t}$, in case of $t=0$ is the beginning of the period (in our case the year 2004) and $t=1$ is the end of the period (in our case the year 2019). Then the increase in exports of the state $(i)$ for a given period is expressed by a relationship $\Delta e_{i}=e_{i}^{1}-e_{t}^{0}$.

We can also write the increment in the form:

$$
\begin{aligned}
& \Delta e_{i}=s_{i}^{0} \Delta E+E^{1} \Delta s_{i}, \\
& \Delta e_{i}=s_{i}^{1} \Delta E+E^{0} \Delta s_{i},
\end{aligned}
$$

where $\Delta E=E^{1}-E^{0}$ and $\Delta s_{i}=s_{i}^{1}-s_{i}^{0}$.

From relations (1) and (2) it is clear that the increase in exports of a given state $(i)$ depends on the growth of exports of all states and the competitiveness of the state, which means the export share of a particular state $(i)$ is expressed as a function of its relative competitiveness, i.e. $s_{i}^{t}=f_{i}^{t}\left(\frac{c_{i}^{t}}{c^{t}}\right)$ and therefore $\Delta s_{i}^{t}=\Delta f_{i}^{t}\left(\frac{c_{i}^{t}}{c^{t}}\right)$.

Kubátová $(2009,2014)$ used Richardson's record (1971) to determine tax competitiveness in the field of corporate tax. The introduction of the method of constant market shares for the area of taxes creates the method of constant tax shares. She applied the method in the field 
of taxation for some EU states. She used an analogous record of corporate tax revenue with exports. Just as a state's exports depend on the growth of a state's total exports and "export competitiveness", the state's corporate tax revenue depends on the growth of total revenue and its "tax competitiveness".

The designations for the area of corporate taxation are as follows:

$\mathrm{cit}_{i}$ - corporate tax revenues of the state $(i)$,

CIT - corporate tax revenues of competing states (including the state $(i)$ ),

$s_{i}=\frac{c i t_{i}}{C I T}$ - state share $(i)$ on total corporate tax revenues (relative competitiveness).

Based on the designations, the relationship for the increase in corporate tax revenues looks as follows:

$$
\Delta c i t_{i}=\operatorname{cit}_{i}^{1}-\operatorname{cit}_{i}^{0}=s_{i}^{0} \Delta C I T+C I T^{1} \Delta s_{i} .
$$

For the needs of the work, the following two relationships are derived, namely the impact of total tax revenue: $\frac{s^{0} \Delta C I T}{\Delta c i t}$, and the impact of tax competitiveness: $\frac{C I T^{1} \Delta s}{\Delta c i t}$.

\section{Method of rate relation}

The method of rate relation was developed analogously by Kubátová (2009) from the authors Junz and Rhomberg (1965). The method analyzes changes in corporate tax rates and their impact on corporate tax revenues. At the same time, it offers an answer to the question of whether states' competitiveness is related to changes in tax rates. Rate relations examine whether changes in the corporate tax rate have an impact on tax revenues and, as a result, contribute to a change in tax competitiveness. The relationship that determines whether there has been an improvement or a deterioration of the rate relation during the observed period is as follows:

$$
\Delta p_{i}=p_{i}^{1}-p_{i}^{0}=\frac{t r_{i}^{1}}{\sum_{i} t r_{i}^{1} \times \frac{c i t_{i}^{1}}{C I T^{1}}}-\frac{t r_{i}^{0}}{\sum_{i} t r_{i}^{0} \times \frac{c i t_{i}^{0}}{C I T^{0}}}
$$

in which it applies:

$p_{i}^{0}$ and $p_{i}^{1}$ - rate relation of state $(i)$ at time $t=0$ and $t=1$,

$t r_{i}^{0}$ - state rate $(i)$ at time $t=0$ and $t r_{i}^{1}-$ state rate $(i)$ at time $t=1$,

$c_{i} t_{i}^{0}$ and $c i t_{i}^{1}$ - corporate tax revenue at time $t=0$ and $t=1$,

$C I T^{0}$ and $C I T^{1}$ - total tax revenues over time $t=0$ and $t=1$, in all competing states (including state $(i))$.

State rate relation we express it in relation to competitors:

$$
\frac{t r_{i}}{\sum_{i} t r_{i} \times \frac{c i t_{i}}{C I T}},
$$

which determines the share rate relation to the weighted average rate of competitors.

\section{RESULTS AND DISCUSSION}

The method of constant tax shares monitors tax competitiveness, where the change in tax revenues in individual states is monitored by two indicators, namely the impact of total tax revenue and the impact of tax competitiveness. 
Fig. 1 Impact of overall revenue growth and competitiveness on corporate revenue growth in EU member states

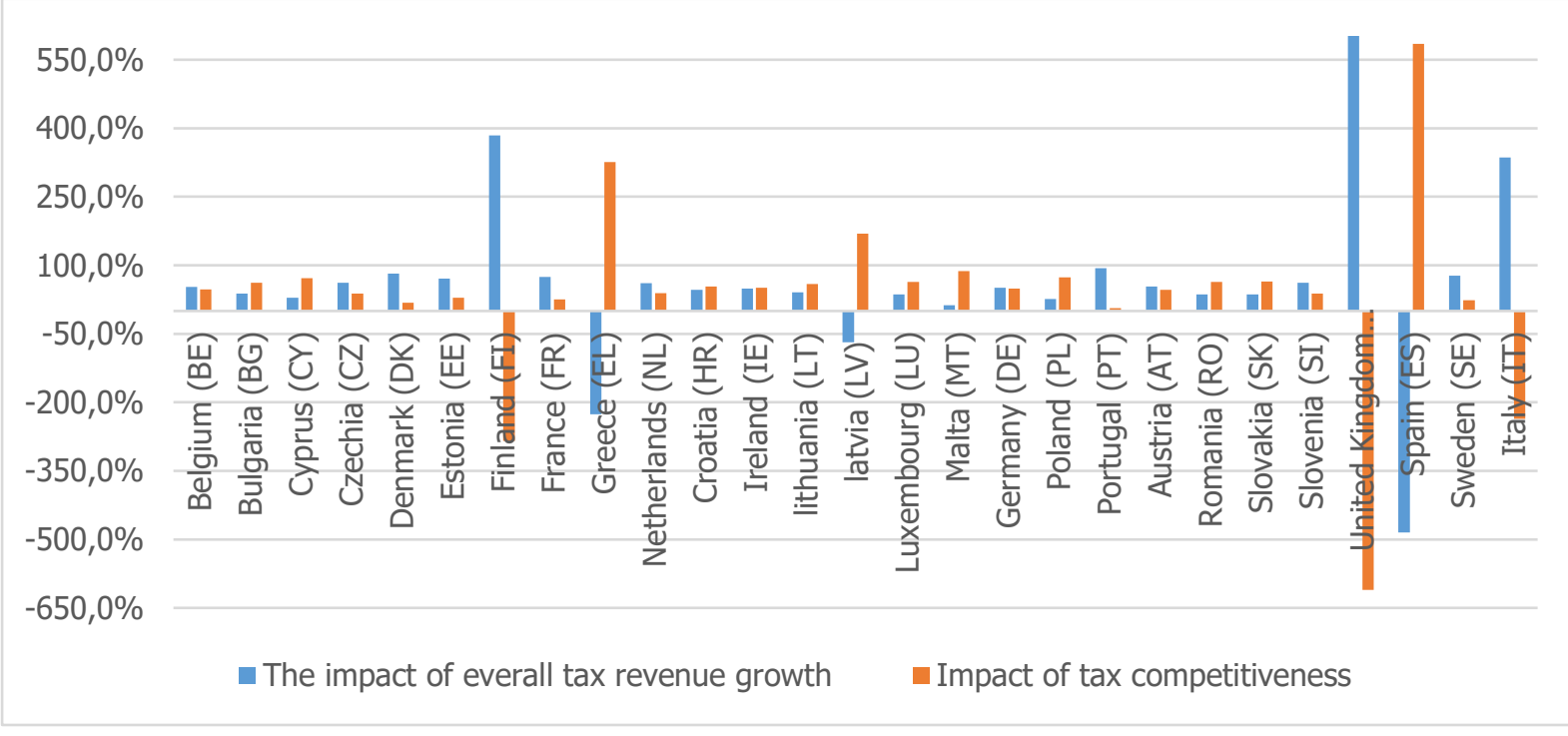

Source: own processing according to Eurostat and European Commission

The least competitive states on the chart (Figure. 1) are United Kingdom, Finland and Italy, despite the significantly higher impact of overall revenue growth, which may have been due to lower statutory rates in those states. On the other hand, the opposite is represented by the states of Spain and Greece, which, with their high impact of competitiveness, achieve negative values of the impact of total tax revenue.

In the table (Table. 1) we can see that increments from corporate tax in absolute terms in the EU states for the compared two periods (2004 and 2019) increased with the exception of three states, namely the old member states Greece and Spain and the new ones. Member states Latvia. Based on the positive values of the indicator of the impact of the overall growth of tax revenue within the $25 \mathrm{EU}$ states, we can assess that it has a positive effect on the growth of tax revenue in these states. The positive impact ranged from $12,4 \%$ in Malta to $710,2 \%$ in United Kingdom. The impact of total tax revenue with a negative impact ranged from $-68,9 \%$ in Latvia to $-484,8 \%$ in Spain. If we compare the total values of the new and old member states, both have a positive effect, but the old member states achieved a higher value, namely $109,5 \%$ compared to the new member states with a value of $37,5 \%$.

The second indicator of the impact of tax competitiveness assesses whether competitiveness causes an increase or decrease in tax revenues in the state. From the calculated values in the table (Table. 1) it is clear that tax competitiveness contributed to the decline in tax revenues in three states (Finland, United Kingdom and Italy). The range of negative impact is from $235,8 \%$ in the Italy to $-610,2 \%$ in United Kingdom. In the other 24 states, the positive growth in tax revenue was driven by the impact of tax competitiveness, ranging from $6,4 \%$ in Portugal to $584,8 \%$ in Spain. The analysis showed that there is a difference between the old and new member states in the given indicator. The new member states recorded a positive impact of tax competitiveness on the change in tax revenues of $62,5 \%$, while the average level is $67,4 \%$. In contrast, the old member states had a negative impact of a total of $-9,5 \%$ with an average of $10 \%$. Another result was Cassette and Patty (2008), whose study of tax competitiveness showed that EU-15 countries (our old member states) are more committed to tax competition than the rest of the EU.

If we look at the share of individual corporate revenues of countries in the total corporate tax revenue of all EU countries, we find that the share of the new member states increased by 
$2.8 \%$ from $4.9 \%$ to $7.7 \%$. In the old member states, the share of total revenue decreased by $2.8 \%$ from $95.1 \%$ to $92.3 \%$.

Table. 1 Impact of overall revenue growth and competitiveness on corporate revenue growth in EU member states and change of rate relation

\begin{tabular}{|c|c|c|c|c|c|c|c|}
\hline \multirow{2}{*}{$\begin{array}{c}\text { State } \\
\text { (state code) }\end{array}$} & \multicolumn{2}{|c|}{$\begin{array}{l}\text { Corporate tax } \\
\text { revenues } \mathrm{cit}_{i}\end{array}$} & \multirow{2}{*}{$\begin{array}{l}\text { Impact of } \\
\text { total tax } \\
\text { revenue } \\
\frac{s^{0} \Delta C I T}{\Delta c i t}\end{array}$} & \multirow{2}{*}{$\begin{array}{c}\text { Impact of tax } \\
\text { competitiveness } \\
\frac{C^{1} T^{1} \Delta s}{\Delta c i t}\end{array}$} & \multicolumn{2}{|c|}{$\begin{array}{c}\text { Statutory tax } \\
\text { rate in } \% \\
t r_{i}\end{array}$} & \multirow{2}{*}{$\begin{array}{c}\text { Change } \\
\text { of rate } \\
\text { relation } \\
\frac{p_{i}^{1}-p_{i}^{0}}{p_{i}^{0}} \\
\end{array}$} \\
\hline & 2004 & 2019 & & & 2004 & 2019 & \\
\hline Belgium (BE) & 8985,9 & 17684,5 & $52,8 \%$ & $47,2 \%$ & 34,0 & 29,6 & $-0,23$ \\
\hline Bulgaria (BG) & 519,4 & 1212,2 & $38,3 \%$ & $61,7 \%$ & 19,5 & 10,0 & $-0,35$ \\
\hline Cyprus (CY) & 468,1 & 1304,2 & $28,6 \%$ & $71,4 \%$ & 10,0 & 12,5 & $-0,46$ \\
\hline Czechia (CZ) & 4034,5 & 7384,2 & $61,6 \%$ & $38,4 \%$ & 28,0 & 19,0 & $-0,17$ \\
\hline Denmark (DK) & 5879,9 & 9549,3 & $81,9 \%$ & $18,1 \%$ & 30,0 & 22,0 & $-0,07$ \\
\hline Estonia (EE) & 54,5 & 93,6 & $71,3 \%$ & $28,7 \%$ & 26,0 & 20,0 & $-0,12$ \\
\hline Finland (FI) & 5357,0 & 6069,0 & $384,6 \%$ & $-284,6 \%$ & 29,0 & 20,0 & 0,33 \\
\hline France (FR) & 40584,0 & 68517,0 & $74,3 \%$ & $25,7 \%$ & 35,4 & 34,4 & $-0,10$ \\
\hline Greece (EL) & 5259,0 & 4071,0 & $-226,3 \%$ & $326,3 \%$ & 35,0 & 28,0 & 0,95 \\
\hline Netherlands (NL) & 16266,0 & 30001,0 & $60,5 \%$ & $39,5 \%$ & 34,5 & 25,0 & $-0,18$ \\
\hline Croatia (HR) & 612,0 & 1285,4 & $46,4 \%$ & $53,6 \%$ & 20,0 & 18,0 & $-0,28$ \\
\hline Ireland (IE) & 5335,0 & 10892,8 & $49,1 \%$ & $50,9 \%$ & 12,5 & 12,5 & $-0,26$ \\
\hline lithuania (LT) & 338,5 & 759,1 & $41,1 \%$ & $58,9 \%$ & 15,0 & 15,0 & $-0,33$ \\
\hline latvia (LV) & 185,1 & 47,7 & $-68,9 \%$ & $168,9 \%$ & 15,0 & 20,0 & 4,87 \\
\hline Luxembourg (LU) & 1571,1 & 3761,1 & $36,7 \%$ & $63,3 \%$ & 30,4 & 24,9 & $-0,37$ \\
\hline Malta (MT) & 128,1 & 657,1 & $12,4 \%$ & $87,6 \%$ & 35,0 & 35,0 & $-0,71$ \\
\hline Germany (DE) & 45218,0 & 90458,0 & $51,1 \%$ & $48,9 \%$ & 38,3 & 29,9 & $-0,24$ \\
\hline Poland (PL) & 4003,7 & 11775,6 & $26,3 \%$ & $73,7 \%$ & 19,0 & 19,0 & $-0,49$ \\
\hline Portugal (PT) & 4308,5 & 6662,1 & $93,6 \%$ & $6,4 \%$ & 27,5 & 31,5 & $-0,02$ \\
\hline Austria (AT) & 5607,0 & 10983,8 & $53,3 \%$ & $46,7 \%$ & 34,0 & 25,0 & $-0,23$ \\
\hline Romania (RO) & 1934,9 & 4685,2 & $36,0 \%$ & $64,0 \%$ & 25,0 & 16,0 & $-0,38$ \\
\hline Slovakia (SK) & 1172,0 & 2840,5 & $35,9 \%$ & $64,1 \%$ & 19,0 & 21,0 & $-0,38$ \\
\hline Slovenia (SI) & 522,9 & 953,5 & $62,1 \%$ & $37,9 \%$ & 25,0 & 19,0 & $-0,17$ \\
\hline $\begin{array}{c}\text { United Kingdom } \\
(\mathrm{UK})\end{array}$ & 57159,7 & 61273,5 & $710,2 \%$ & $-610,2 \%$ & 30,0 & 19,0 & 0,41 \\
\hline Spain (ES) & 28793,0 & 25757,0 & $-484,8 \%$ & $584,8 \%$ & 35,0 & 25,0 & 0,69 \\
\hline Sweden (SE) & 8511,4 & 14169,2 & $76,9 \%$ & $23,1 \%$ & 28,0 & 21,4 & $-0,09$ \\
\hline Italy (IT) & 30123,0 & 34708,0 & $335,8 \%$ & $-235,8 \%$ & 37,3 & 27,8 & 0,31 \\
\hline $\begin{array}{c}\text { Sum of all EU } \\
\text { states }\end{array}$ & 282932,1 & 427555,6 & & & $26,9 *$ & $22,2 *$ & $0,07 *$ \\
\hline $\begin{array}{c}\text { New member } \\
\text { states }\end{array}$ & 13973,6 & 32998,3 & $37,5 \%$ & $62,5 \%$ & $21,4^{*}$ & $18,7^{*}$ & $0,09 *$ \\
\hline $\begin{array}{l}\text { Old member } \\
\text { states }\end{array}$ & 268958,5 & 394557,2 & $109,5 \%$ & $-9,5 \%$ & $31,4^{*}$ & $25,1^{*}$ & 0,06* \\
\hline
\end{tabular}

Source: own processing according to Eurostat and European Commission 
In the table (Table. 1$) *$ are marked average values. Tax competition is strong in EU states, as evidenced by the decline in average tax rates (Crabbé \& Vandenbussche, 2013). At the statutory rate, we can see its average decline from $26,9 \%$ to $22,2 \%$ within the EU member states. When dividing states into new and old member states, a more significant decrease is visible in the old states, from $31,4 \%$ to $25,1 \%$. However, for the new member states, the average value of the statutory rate is comparatively lower. As Clausing (2011) points out, tax competitiveness in the area of lower tax rates may affect the business and investment environment, creating a more attractive space for the investor, which may result in higher tax revenues.

Kubátová (2009) and Mihóková et al. (2018) state in their studies that the new member states that joined the EU after 2004 are more competitive than the old member states. States are often criticized for their tax policies and lower tax rates. Our analysis, based on empirical data, has shown that the new member states are more competitive than the old member states, and thus confirms the authors' assertion. The old member states have been trying to increase corporate tax revenues since the new member states have joined the EU and have shown a greater degree of competitiveness, as indicated by the reduction in statutory rates. However, they did not show a sufficient degree of competitiveness to overcome the new member states. The result is complemented by the average statutory rates of the old member states, which decreased during the period under review, which can be considered an indication of competition, but were still comparably higher than in the new member states. The finding of Devereux et al. (2008) that states with higher tax rates are more responsive to changes in other states' rates.

The method of rate relations reveals whether changes in corporate tax rates in the period under review affect corporate income and whether there has been a change in tax competitiveness. Based on the method, the values of the rate relations for 2004 and 2019 were compared (Table. 1). The growth of rate relations was recorded in six states, of which Latvia, Greece and Spain had significant values. The decrease was recorded in twenty-one states, where Cyprus, Malta and Poland had the lowest values. The range of rate relations is from a maximum of $478 \%$ in Latvia to $-71 \%$ in Malta. Within the division of the old (10 states) and new (11 states) member states, negative values dominate. The positive changes in rate relations were dominated by the five old member states.

The impact of total tax revenue and the impact of tax competitiveness, together with the change in rate relations on the increment of corporate revenues, were divided into three groups based on their mutual impact (Table. 2). The first group consists of the most significant number of twenty-one states, while the number of old (10 states) and new (11 states) member states is almost the same. It is presented by a negative change in rate relation, which together with the positive impact of total tax revenues and the impact of tax competitiveness. This combination has led to an increase increment in tax revenues. The results of the first group agree with the results of Mihóková et al. (2018), which emphasize the positive impact of total tax revenue along with the impact of competitiveness on tax revenue growth. The three old member states represent the second group. There is a positive change in the rate relation together with the impact of total tax revenue with a negative impact of competitiveness, which causes a positive change in tax revenues. The last third group is represented by three states, where only one is a new member state. The decrease in the increment in tax revenues within this group was influenced by the overall decrease in tax revenues, although the value of the rate relation was positive together with the positive impact of tax competitiveness. 
Table. 2 Mutual interaction of indicators

\begin{tabular}{|c|c|c|c|c|c|}
\hline \multicolumn{2}{|c|}{ States EU-27 } & \multirow{2}{*}{$\frac{s^{0} \Delta C I T}{\Delta c i t}$} & \multirow{2}{*}{$\frac{C I T^{1} \Delta s}{\Delta c i t}}$. & \multirow{2}{*}{$\Delta p_{i}$} & \multirow{2}{*}{$\Delta c i t$} \\
\hline Old member states EU-15 & New member states EU-12 & & & & \\
\hline $\begin{array}{c}\mathrm{BE}, \mathrm{DK}, \mathrm{FR}, \mathrm{NL}, \mathrm{IE}, \mathrm{LU}, \mathrm{DE}, \\
\mathrm{PT}, \mathrm{AT}, \mathrm{SE}\end{array}$ & $\begin{array}{c}\text { BG, CY, CZ, EE, HR, LT, } \\
\text { MT, PL, RO, SK, SI }\end{array}$ & + & + & - & + \\
\hline FI, UK, IT & - & + & - & + & + \\
\hline $\mathrm{EL}, \mathrm{ES}$ & LV & - & + & + & - \\
\hline
\end{tabular}

Source: own processing according to Eurostat and European Commission

Following the accession of new member states to the EU, there was a clear reduction in statutory tax rates, which had the effect of increasing tax competitiveness (Podviezko et al., 2019). Based on the rate relation method, we can conclude that changes in rate relations are significant and thus have an impact on the tax competitiveness of states. This is also confirmed by statutory tax rates, the changes in which have affected the growth or decline in the competitiveness of states. Mihóková et al. (2018) came to the opposite conclusion, where they claimed that the change in tax competitiveness and the change in tax revenue in the state are not affected by a negative resp. positive rate relation. At the same time, Kubátová (2009) states that it is clearly not possible to use tax competitiveness in EU states, accompanied by lower tax rates, to achieve an increase in the share of corporate tax revenues.

\section{CONCLUSION}

Since its inception, the European Union wants to achieve harmonization and the creation of an effective corporate tax system. The aim of the effort is to ensure support for the sustainable growth of states with a balanced tax burden. Despite many years of efforts, tax harmonization has not yet taken place due to the diverse structure of tax systems. Member states want to attract as much investment as possible, which can increase corporate tax revenue. The situation creates space for tax competitiveness between EU states.

Using the methods of constant tax shares and rate relations, we tried to achieve the set goal based on empirical data, namely whether changes in corporate taxation have an impact on the tax competitiveness of EU states. The method of constant tax shares, which includes an analysis of the impact of tax revenue and the impact of tax competitiveness on tax revenue in EU states, has shown that tax revenues in the old member states are higher in absolute terms than in the new Member States, but the increment in revenue growth is in the old member states $46,7 \%$, while in the new member states it is higher at $136,1 \%$. The set goal was complemented by the hypothesis, which was confirmed, namely that the new member states are more competitive than the old EU member states. Any change in the rate relations and statutory tax rate has shown an impact on the change in the tax competitiveness of states, while in the twenty-four EU states it has led to an increase increment in corporate tax revenue. The presence of a decline in the rate relation affected tax competitiveness in twenty-one EU states. The conclusion of the thesis is the finding that changes in corporate tax have an impact on the tax competitiveness of EU states. 


\section{ACKNOWLEDGEMENT}

This research was supported by VEGA project No. 1/0430/19 Investment decision-making of investors in the context of effective corporate taxation.

\section{REFERENCES}

Ahmadi-Esfahani, F., \& Anderson, G.M. (2006). Constant Market Shares Analysis:Uses, Limitations and Prospects. Australian Journal od Aqricultural and Resource Economics, 50(4), 1-17. https://doi.org/10.22004/ag.econ.116983.

Bradford, D., \& Oates, W. (1971). The Analysis of Revenue Sharing in a New Approach to Collective Fiscal Decisions. The Quaerterly Journal of Economics, 85(3), 416-439. https://doi.org/10.2307/1885931.

Bunn, D., \& Asen, E. (2019). International Tax Competitiveness Index. Washington, D. C.: Tax Foundation. $\quad 20$ Retrieved November 2020, from https//files.taxfoundation.org/20190930115625/2019-International-Tax-CompetitivenessIndex.pdf.

Cassette, A., \& Paty S. (2008). Tax competition among Eastern and Western European countries: With whom do countries compete? Economic Systems, 32(4), 307-325. https://doi.org/10.1016/j.ecosys.2008.06.003.

Clausing, K. A. (2011). In Search of Corporate Tax Incidence. Tax Law Review, 65(3), 433472. https://doi.org/10.2139/ssrn.1974217.

Crabbé, K., \& Vandenbussche H. (2013). Are Your Firm's Taxes Set in Warsaw? Spatial Tax Competition in Europe. FinanzArchiv: Public Finance Analysis, 69(3), 317-337. https://doi.org/10.1628/001522108X671146..

Devereux, M., Lockwood, B., \& Redoano, M. (2008). Do countries compete over corporate taxes? Journal of Public Economics, 92, 1210-1235. https://doi.org/10.1016/j.jpubeco.2007.09.005

Devereux, M.P., \& Loretz, S. (2012). What do We Know about Corporate Tax Competition? Oxford University Centre for Business Taxation. Working Paper No. 12/29.

Dyadkova, M., \& Momchilov, G. (2014). Constant Market Shares Analysis Beyond the Intensive Margin of External Trade. Bulgarian National Bank. Bulgaria Discussion Papers No. DP/94/2014.

European Commission (2020). Retrieved 05 November 2020, from https://ec.europa.eu/taxation_customs/business/economic-analysis-taxation/datataxation_en.

Eurostat Statistics (2020). Retrieved 02 November 2020, from http://ec.europa.eu/eurostat/data/database.

Eurostat Statistics (2020). Retrieved 02 November 2020, from https://ec.europa.eu/eurostat/statistics-explained/index.php/Tax_revenue_statistics.

HAMEAKERS, H. (1993). Fiskal Sovereignity and Tax Harmonization in the EC. European Taxation, 33(1), 25-27. ISSN 0014-3138.

Haufler, A., \& Stähler, F. (2013). Tax Competition in a Simple Model with Heterogeneous Firms: How Larger Markets Reduce Profit Taxes. International Economic Review, 54(2), 665-692. https://doi.org/10.1111/iere.12010. 
Jiménez, N., \& Martín, E. (2010). A constant market share analysis of the euro area in the period 1994-2007. Economic Bulletin, Banco de España;Economic Bulletin Homepage, issue JAN, 1-15. Retrieved 06 December 2020, from https://www.bde.es/f/webbde/Secciones/Publicaciones/InformesBoletinesRevistas/BoletinEco nomico/art4_jan.pdf.

Junz, H.B., \& Rhomberg, R.R. (1965). Prices and Export Performance of Industrial Countries, 1953-63. Staff Papers (International Monetary Fund), 12(2), 224-271. https://doi.org/10.5089/9781451947212.024.A003.

Kubátová, K. (2009). Analýza daňové konkurenceschopnosti u daně z přjijmů korporací v EU. XIV. ročník mezinárodní konference Teoretické a praktické aspekty veřejných financí. Praha: Nakladatelství Oeconomica.

Kubátová, K. (2014). Long-term Tax Competitiveness of the New Member States Compared to the Original EU Members. Acta academica karviniensia, 14(2), 48-57. https://doi.org/10.25142/aak.2014.027.

Mihóková, L., Andrejovská, A., \& Martinková, S. (2018). Daňová konkurencieschopnost' členských krajín Európskej Únie v kontexte korporátneho zdanenia. Politická ekonomie, 66(5), 588-608. https://doi.org/10.18267/j.polek.1206.

OATES, W. (1972). Fiscal federalism. American Political Science Review, 1974, 68(4), 17771778. https://doi.org/10.2307/1959998.

Podviezko, A., Parfenova, L., \& Pugachev, A. (2019). Tax competitiveness of the new EU member states. Journal of Risk and Financial Management, 12(1), 34. https://doi.org/10.3390/jrfm12010034.

Richardson, J.D. (1971). Constant-market-shares Analysis of Export Growth. Journal of International Economics, 1(2), 227-239. https://doi.org/10.1016/0022-1996(71)90058-4.

Skriner, E. (2009). Competitiveness and specialisation of the Austrian export sector: A constant-market-shares analysis. Reihe Ökonomie/Economics Series. Working Paper No. 235.

Smith, S. (2008). Restraining the GoldenWeed: Taxation and Regulation of Tobacco. FinanzArchiv/Public Finance Analysis, 476-507. https://doi.org/10.1628/001522108X397697.

Stiglitz, J.E., Rosengard, J. K. (2015). Economic of the Public Sector. W.W. Norton \& Company. ISBN 978-03939665-10.

Teera, J.M., Hudson, J. (2004). Tax Performance: a Comparative Study. Journal of International Development, 16(6), 785-802. https://doi.org/10.1002/jid.1113.

TIEBOUT, CH.M. (1956). A Pure Theory of Local Expenditures. The Journal of Political Economy, 64(5), 416-424. http://dx.doi.org/10.1086/257839.

Tyzsinski, H. (1951). World Trade in Manufactured Commodities, 1899-1950. The Manchester School, 19(3), 272-304. https://doi.org/10.1111/j.1467-9957.1951.tb00012.x.

Wigger, B., \& Wartha, U. (2003). How to Allocate the Power to Tax in Europe? in Holler, M. J., ed., European Governance, Tübingen: Mohr Siebeck. ISBN 978-3-16-148219-9.

Wilson, J. (1999). Theories of Tax Competition. National Tax Journal, 52(2), 269-304. https://doi.org/10.1086/NTJ41789394. 